\title{
The effect of "invisible" tax preferences on investment and tax preference measures is
}

\author{
Leslie A. Robinson ${ }^{\mathrm{a}}$, Richard Sansing ${ }^{\mathrm{a}, \mathrm{b}, *}$ \\ ${ }^{a}$ Tuck School of Business at Dartmouth, 100 Tuck Hall, Hanover, NH 03755, USA \\ ${ }^{\mathrm{b}}$ Tilburg University, Tilburg, The Netherlands
}

Received 5 January 2007; received in revised form 17 September 2007; accepted 20 September 2007

Available online 26 October 2007

\begin{abstract}
This paper develops and analyzes a model in which tax considerations and financial reporting considerations have countervailing effects on a firm's investments in internally developed intangible assets. It also proposes and estimates a new measure of tax preferences, which we call the economic effective tax rate. This measure reflects both investments in intangible assets and the use of debt financing, neither of which generates a book-tax difference. Our measure indicates that the economic effective tax rate was about 18 percent between 1988 and 2005, when the statutory tax rate was either 34 or 35 percent.
\end{abstract}

(C) 2007 Elsevier B.V. All rights reserved.

JEL classification: $\mathrm{H} 25 ; \mathrm{M} 41$

Keywords: Intangible assets; Tax preferences; Effective tax rates; Financial reporting costs

\section{Introduction}

We investigate two consequences of the immediate expensing of investments in internally developed intangible assets for both tax and financial reporting purposes. First, we present a model in which both the tax advantages and financial reporting disadvantages of immediate expensing affect firm investment decisions. We show that the optimal ratio of investment in intangible assets to tangible assets could be greater than or less than the ratio from a hypothetical benchmark case in which intangible assets have neither tax advantages nor financial reporting disadvantages. This paper is similar in spirit to Shackelford et al. (2006) in that both accounting and taxable income are important to firm managers. Our setting allows us to explore the trade-off between tax incentives and financial reporting considerations through an economic model of firm investment

\footnotetext{
${ }^{2}$ We thank Sanjay Gupta, Christian Leuz, Tom Neubig, Ed Outslay, Emmanuel Saez, Ross Watts, participants at the NBER PreConference on Financial Reporting and Taxation, the ATPI Conference on the Intersection of Tax Policy and Financial Reporting, the NBER Conference on Financial Reporting and Taxation and an anonymous referee for helpful comments.

*Corresponding author. Tuck School of Business at Dartmouth, 100 Tuck Hall, Hanover, NH 03755, USA. Tel.: + 16036460392 ; fax: +16036461308

E-mail address: Richard.C.Sansing@dartmouth.edu (R. Sansing).
} 
in which financial reporting considerations enter the manager's objective function endogenously via the effect of accounting disclosures on stock price. The economic model we develop illustrates how tax and financial accounting reporting rules have countervailing effects on corporate investment in internally developed intangible assets.

Second, we propose a measure of the extent to which a firm's activities are tax-favored due to investments in intangible assets and the use of debt financing. Investments in intangible assets are expensed instead of capitalized and depreciated, while the use of debt financing yields tax-deductible interest expense payments instead of non-deductible dividend payments. Both investments in intangible assets and interest payments are expensed for both tax and financial reporting purposes and therefore do not generate book-tax differences. Accordingly, these fundamental investment and financing choices do not reduce the firm's accounting effective tax rate, but they do reduce the government's claim on the firm's pre-tax cash flows. Our measure, which we call the economic effective tax rate, reflects the effects of investments in intangible assets and uses of debt financing on a firm's tax burden, which traditional financial accounting measures of tax preferences fail to capture. We estimate that firms faced an average economic effective tax rate of about 18 percent between 1988 and 2005 , during which time the statutory rate was either 34 or 35 percent. On average, about half of the difference between our measure and the statutory tax rate is attributable to intangible assets and about half is attributable to the use of debt financing. Both the effect of intangible assets and the use of debt financing on our measure vary across industries. The effect of intangible assets increased between 1988 and 2005, whereas the effect of debt financing remained relatively stable over that time period.

Both issues that we explore arise because external users of accounting information are unable to distinguish investments in internally developed intangible assets from operating expenses. The inability of investors to distinguish investments in intangible assets from operating expenses gives the firm manager an incentive to decrease such investments in an effort to boost stock price. The inability of policy makers to distinguish investments in intangible assets from operating expenses makes it difficult to evaluate the extent to which firms benefit from "invisible" tax preferences that do not create book-tax differences. Finally, the corporate finance literature indicates that investment in tangible, as opposed to intangible assets, supports more debt. ${ }^{1}$ Consistent with this literature, we find that the effects of intangible assets and the effects of debt financing on our tax preference measure are negatively correlated, resulting in less intra-industry variation when both tax preferences are considered simultaneously.

It is important to emphasize the issues that we do not try to address in this paper. This is not a policy prescription paper arguing for or against the current system of tax and financial reporting for internally developed intangible assets. Investments in internally developed intangible assets are expensed instead of capitalized for both tax and financial reporting purposes because of two practical difficulties with capitalization. First, it is difficult to measure intangible assets arising from private investment, which is needed in order to determine the amount to capitalize. Second, it is difficult to ascertain when intangible investments have lost their value, which is needed in order to determine when the investment should be expensed. We accept the expensing of intangible investments for tax and financial reporting purposes as given, and compare the investment decisions under the current system to those under two hypothetical benchmark alternatives under which intangible assets are observable in order to highlight the economic tension between tax and financial reporting in the model. Specifically, we demonstrate that the tax treatment of investments in internally developed intangible assets and the financial reporting treatment of these investments produce countervailing effects on the optimal mix of intangible and tangible investments that the firm makes.

In Section 2, we discuss previous research on intangible assets and tax preference measures. In Section 3, we extend the model developed by Kanodia et al. (2004) by incorporating a tax effect into their model and show the countervailing effects of taxes and financial reporting on the firm's investment decisions. In Section 4, we derive a measure of tax preferences by modeling the firm as a collection of projects that feature both tangible and intangible investments that are in part financed with tax-favored debt. In Section 5, we estimate our measure for U.S. firms between 1988 and 2005. Section 6 concludes. All proofs are in Appendix A.

\footnotetext{
${ }^{1}$ Myers (1977) develops a model that predicts the debt-to-value ratio will be lower the larger the proportion of firm value represented by intangible, rather than tangible assets, while Smith and Watts (1992) provided empirical support to Myers' claim.
} 


\section{Previous research}

\subsection{Investments in internally developed intangible assets}

Internally developed intangible assets are an important and growing source of firm value. These investments include the development of intellectual property (including, but not limited to, R\&D expenditures), the creation of brand value via advertising, and the generation of firm-specific human capital. The rise in importance of these assets strains existing systems of financial and tax accounting, which evolved in an era in which tangible and financial assets were the dominant sources of firm value. This strain arises because in general, firms expense investments in internally developed intangible assets for both tax and financial reporting purposes. Blair and Wallman (2001) provide an overview of the economic, accounting and taxation issues associated with intangible assets.

Our interpretation of intangible assets is an expansive one. While intangible assets include legally protected intellectual property such as patents, it is not limited to what would be regarded as property in a legal sense. It includes firm-specific human capital of the workforce and organizational capital such as Wal-Mart's computerized supply chain. An intangible asset is a claim to future benefits that does not have a physical or financial embodiment (Lev, 2001, p. 5). At the broadest level, we distinguish investments in intangible assets from operating expenses, which consist of direct labor, direct materials, manufacturing overhead, marketing and administrative expenses that support current-period revenues with no direct effect on future cash flows (Kanodia et al., 2004, p. 96).

The literatures in public finance economics and financial accounting frame the debate over investments in intangible assets in very different ways. Public finance economists note that the ability to expense investments in intangible assets when made provides them with an effective tax rate of zero, which represents a substantial departure from tax neutrality (Gravelle, 1994, p. 209). Therefore, public finance economists generally claim that a zero effective tax rate induces excessive private investment in intangible assets. ${ }^{2}$

More recent corporate tax policy debates surrounding tax incentives and corporate investment have focused on the increasing importance of intangible assets, and the fact that these assets are already being expensed under current law. Both Neubig (2006) and Sullivan (2006) point out that tax incentives that offer immediate expensing or accelerated depreciation of investments in tangible property are less desirable than tax rate reductions, because many investments are in the form of internally developed intangible assets that are already expensed under current law.

The financial accounting literature, in contrast, largely reflects a view that accounting for investments in intangible assets as expenses rather than assets induces underinvestment. Lev (2001, p. 95) argues that the inability of investors to distinguish operating expenses from investments in intangible assets creates an information asymmetry that raises the cost of capital from such investments, thereby deterring them. Kanodia and Mukherji (1996) and Kanodia et al. (2004) develop this idea in formal models of firm investment decisions when capital market participants cannot distinguish operating expenses from investments in internally developed intangible assets. These models show that the non-observability of intangible investments creates an incentive for the firm to cut back on these investments relative to a world in which investors could disentangle investments in intangible assets from operating expenses.

\subsection{Tax preference measures}

The accounting literature on the measurement of tax preferences has focused on the accounting effective tax rate, the ratio of tax expense to pre-tax book income (Gupta and Newberry, 1992; Shevlin and Porter, 1992), or on related measures driven by book-tax differences (Wilkie, 1992; Wilkie and Limberg, 1993).

Fullerton and Lyon (1988) show that effective tax rate measures that exclude the taxation of intangible capital are misleading. In an analysis restricted to investments in R\&D and advertising, they estimate the effect of expensing these investments for the 1983 tax year. They estimate that about 11 percent of the assets in their

\footnotetext{
${ }^{2}$ This excessive investment could be socially beneficial, however, to the extent that intangible investments generate positive externalities because the firm cannot capture all of the benefits these investments create.
} 
sample were associated with intangible assets. McGrattan and Prescott (2000) take a more expansive view of intangibles and study a later time period (1990-1999). The authors find that about 38 percent of the assets in the corporate sector are intangible assets. We measure the value of a firm's intangible assets by taking the difference between the market value of the claims to the firm's assets and the book value of the firm's assets using aggregate measures across firms from 1988 through 2005. Using our approach, we estimate that about 33 percent of total firm assets in our sample are intangible assets, suggesting that our measure of intangible assets is on the conservative side.

Our tax preference measure is similar in spirit to Dunbar and Sansing (2002), who examine the ratio of tax expense to the pre-tax market return on equity. Our results suggest an average economic effective tax rate, ignoring the effects of debt financing, of about 26 percent between 1992 and 1996; the Dunbar and Sansing (2002) explicit tax rate measure is about 26 percent over the same time period.

\section{Economic model of the tension between tax and financial reporting}

\subsection{Basic model}

A firm has access to a production technology that transforms current investments in tangible assets $(K)$ and intangible assets $(N)$ into output $(q)$ in the following fashion:

$$
f(K, N)=q .
$$

The firm chooses its investments on date zero. The production technology generates output $q$ on date one and on each succeeding date as long as both assets remain productive. Each unit of output generates an expected operating cash flow of $\mu>0$. The date one operating cash flow, denoted by $x$, is drawn from a continuous probability distribution with strictly positive support on the interval $[\underline{x}, \infty)$, and has a mean of $\mu q$ and a variance of $\sigma^{2}$. The lower bound $\underline{x}$ is sufficiently high that the firm is better off if it operates the project instead of liquidating it.

On each date $j$ after the cash flow is received, the productivity of the intangible assets drops to zero with probability $\lambda$ and the project is abandoned. With probability $1-\lambda$, the project continues to generate positive operating cash flows in the future, where the expected cash flow on date $j+1$ is equal to the realized cash flow on date $j$. When the project is abandoned, the tangible assets survive with no reduction in value and are either sold at their historical cost $K$ or redeployed within the firm in a new project. The intangible assets generate no further value to the firm once the project is abandoned.

The firm operates in a single taxing jurisdiction. Operating cash flows are taxed at a rate of $\tau$. The tangible investment $K$ is neither expensed nor depreciated for tax purposes because the tangible assets do not decrease in value over time. The intangible investment $N$ is either expensed or capitalized for purposes of computing taxable income. The firm chooses investments $K$ and $N$ to maximize the present value of the after-tax cash flows that the project generates, discounted at the project's after-tax weighted average cost of capital (WACC) $\rho$, less the after-tax cost of the investments.

We focus on the ratio of intangible investments to tangible investments $N / K$ in this study because this provides a natural way to see how tax and financial reporting considerations affect the composition of the firm's capital stock. ${ }^{3}$ To do this, we impose additional structure on the problem by assuming that the firm has access to a Cobb-Douglas production technology of the form

$$
f(K, N)=K^{\alpha} N^{\beta}
$$

with the productivity parameters $\alpha>0, \beta>0$, and $\alpha+\beta<1$. This functional form is consistent with the idea that investments in intangible assets and investments in tangible asset are made to support each other.

\footnotetext{
${ }^{3}$ In contrast to Kanodia et al. (2004), which examines the economic effects of accounting policy choices for measuring and reporting investments in intangible assets, we do not examine such policy implications. Our hypothetical benchmark case where there are neither tax advantages nor financial reporting disadvantages (i.e., full information under the capitalization regime) cannot feasibly be implemented. Therefore, the welfare comparisons that were made in Kanodia et al. (2004) are not a useful exercise in the context of our study.
} 
Table 1

Investment environments under different tax and financial reporting systems

\begin{tabular}{llll}
\hline & Benchmark capitalization case & Benchmark expensing case & Aggregated disclosure case \\
\hline Tax regime & Capitalize intangibles & Expense intangibles & Expense intangibles \\
Financial reporting environment & Full information & Full information & Accounting information \\
$N^{*}$ & $\frac{\beta \rho}{\alpha[\rho+\lambda(1-\tau)]}$ & $\frac{\beta \rho}{\alpha(1-\tau)(\rho+\lambda)}$ & $\frac{\beta[\rho(1+\rho)-\theta(1-\lambda)(1-\tau)]}{\alpha(1-\tau)\left(1+\rho+\rho^{2}+\rho \lambda\right)}$ \\
& Proposition 1(a) & Proposition 1(b) & Proposition 2 \\
\hline
\end{tabular}

\subsection{Investment environment}

Tax and financial reporting systems jointly create an investment environment in which a firm makes its investment choices. The tax regime affects a firm's investment decisions by changing the timing of deductions. We consider two tax regimes. Under the tax expensing regime, the full amount of the investment $N$ is deducted in computing taxable income on date zero. Under the tax capitalization regime, the full amount of the investment $N$ is capitalized and subsequently deducted in computing taxable income under Internal Revenue Code $\S 165$ when the project is abandoned. The tax expensing regime provides a timing advantage relative to the tax capitalization regime.

The disclosures provided by the financial reporting environment also affect a firm's investment decisions. In the full information environment, investors can observe the firm's investment $N$. In the accounting information environment, investors cannot directly observe $N$, but instead infer it from other directly observable information. With full information, investors are able to disentangle investments in intangible assets from operating expenses. Accordingly, the full information environment has a disclosure advantage relative to the accounting information environment. ${ }^{4}$

Table 1 summarizes the different investment environments created by the interaction of tax and financial reporting systems. We distinguish among three cases in our analysis. Two cases we consider are hypothetical benchmark cases that feature a full information environment in which both investors and the tax authority observe $N$. One of these cases features the tax capitalization regime, which we refer to as the benchmark capitalization case; the other features the tax expensing regime, which we refer to as the benchmark expensing case. The third case corresponds to the actual environment in which firms operate, which features the accounting information environment and the tax expensing regime. We refer to this case as the aggregated disclosure case.

\subsection{Effect of the tax system on investment in the full information environment}

Here we establish the investment incentives created by the tax system in the full information environment. We frame the analysis in terms of the investment ratio $N^{*} / K^{*}$ to show how taxes and financial accounting disclosures affect the mix of intangible and tangible investments used to pursue a project. We compare the investment ratio in the benchmark capitalization case to the investment ratio in the benchmark expensing case. This comparison shows that the tax expensing regime unambiguously increases the investment ratio $N^{*} / K^{*}$ in the full information environment.

Given investments $K$ and $N$, the present value of a project's expected after-tax cash flows, not including the after-tax cost of the investments, is

$$
\sum_{j=1}^{\infty} \frac{[(1-\tau) \mu q+\lambda K](1-\lambda)^{j-1}}{(1+\rho)^{j}}=\frac{(1-\tau) \mu q+\lambda K}{\rho+\lambda}
$$

\footnotetext{
${ }^{4}$ One could also think of our information environments in the context of Kanodia et al. (2004). Our full information environment corresponds to their intangibles measurement regime in the special case of no measurement error (the full information regime); our accounting information environment corresponds to their expensing regime.
} 
Under the capitalization regime, the firm's date zero maximization problem is

$$
\max _{K, N}\left\{\frac{(1-\tau) \mu f(K, N)+\lambda(K+\tau N)}{\rho+\lambda}-K-N\right\} \text {. }
$$

Under the expensing regime, the firm's date zero maximization problem is

$$
\max _{K, N}\left\{\frac{(1-\tau) \mu f(K, N)+\lambda K}{\rho+\lambda}-K-N(1-\tau)\right\} .
$$

Using (4) and (5), we can see that the expensing regime is more favorable than the capitalization regime. We show this by comparing the after-tax cost of the intangible investment under the expensing regime, $N(1-\tau)$, to the after-tax cost of the intangible investment under the capitalization regime, $N(1-(\tau \lambda / \rho+\lambda))$.

Proposition 1 presents the investment ratio $N^{*} / K^{*}$ associated with the solutions to the firm's maximization problem in the benchmark capitalization case characterized in (4) and the benchmark expensing case characterized in (5).

Proposition 1. In the full information environment:

(a) under the tax capitalization regime,

$$
\frac{N^{*}}{K^{*}}=\frac{\beta \rho}{\alpha[\rho+\lambda(1-\tau)]} \text { and }
$$

(b) under the tax expensing regime,

$$
\frac{N^{*}}{K^{*}}=\frac{\beta \rho}{\alpha(1-\tau)(\rho+\lambda)} .
$$

A comparison of the investment ratios in proposition 1 shows that in the full information environment, $N^{*} / K^{*}$ is higher under the tax expensing regime than under the tax capitalization regime. The difference is increasing in the tax rate $\tau$ and the project's after-tax WACC $\rho$, and is decreasing in the probability $\lambda$ that the intangible assets will stop being productive.

\subsection{Effect of the accounting information environment}

Having established the ratio of intangible to tangible investments in the full information environment under each tax regime, we turn to a model of firm investment behavior in a setting in which accounting measures of the firm's investment decisions are of first-order importance. By comparing the investment ratio in the aggregated disclosure case to the investment ratios in the two benchmark cases, we can identify the trade-off between tax considerations that induce investment in internally developed intangible assets, and financial reporting considerations that deter these investments.

The aggregated disclosure case, which corresponds to the real-world investment environment, has three important properties. First, investments in internally developed intangible assets are expensed for tax purposes when the expenditure is made, i.e., the firm operates under the tax expensing regime. Second, the accounting system exhibits book-tax conformity in that the investments in internally developed intangible assets are also expensed for financial reporting purposes. Third, the accounting system exhibits income aggregation in that the accounting system reports period one pre-tax operating income of $y=x-N$. The accounting report does not decompose $y$ into its two components, where $x$ is the firm's date one operating cash flow and $N$ is the firm's date zero investment in intangible assets. ${ }^{5}$ The tax expense for financial reporting purposes on date one is $\tau y$.

\footnotetext{
${ }^{5}$ In practice, there is a continuum of disclosure about a firm's investments in intangible assets. For example, some firms disclose R\&D and advertising as a line item on the face of the income statement. Our model considers only two cases: full information about intangible assets or no information about intangible assets. This helps to highlight the effect of the information environment on firm's investments in intangible assets and is consistent with our expansive view of intangible assets beyond those created by R\&D and advertising.
} 
The accounting report issued at the moment that the first period operating cash flow is realized is a vector $(y(1-\tau), K)$, where the first element is the project's after-tax operating accounting income and the second element is the project's tangible assets.

On date zero, the firm makes its investment choices $K$ and $N$ at an after-tax cost of $K+N(1-\tau)$. Investors are not able to observe these choices. On date one, four events occur. First, the firm receives its operating cash flow $x$ and pays taxes of $\tau x$, retaining the difference. Second, the firm issues the accounting report $(y(1-\tau), K)$. Third, the current investors sell their ownership interests to the next generation of investors. Current investors must sell their interests; competition among the next generation of investors forces the price to be equal to the present value of future cash flows that the project generates, conditional upon the accounting report. Fourth, the firm observes whether the project will generate cash flows in the future. If it will not, the project is abandoned and the tangible assets are sold for $K$.

To illustrate the importance of the aggregated income report of $y$, consider first the price $P$ of the investors' ownership interests if the investors could observe the two components of $y, x$ and $N$. If the investors knew $x$, they would know that expected future operating cash flows would continue to be $x$ for as long as the intangible assets were productive, because the expected cash flow on date $j+1$ is equal to the realized cash flow on date $j$. Using this information, investors would set the price of the claims to the firm's assets on date one equal to

$$
P=\lambda K+\sum_{j=1}^{\infty} \frac{[(1-\tau) x+\lambda K](1-\lambda)^{j}}{(1+\rho)^{j}}=\frac{x(1-\tau)(1-\lambda)+\lambda K(1+\rho)}{\rho+\lambda} .
$$

In this case, from the perspective of date zero, the present value of the project's future after-tax cash flows would be the sum of the expected price $P$ from (6) and the expected date one after-tax cash flow, discounted one period. Using the relation $E(x)=\mu q(K, N)$, this amount is

$$
\frac{(1-\tau) \mu q}{1+\rho}+\frac{(1-\tau) \mu q(1-\lambda)+\lambda K(1+\rho)}{(\rho+\lambda)(1+\rho)}=\frac{(1-\tau) \mu q+\lambda K}{\rho+\lambda},
$$

which is the same as (3). So with a disaggregated accounting report, the firm would choose the investments on date zero consistent with the benchmark expensing case. That is, the tax system of immediate expensing would have the intended incentive effect.

However, on date one, investors face a valuation problem because of their inability to observe $x$. Investors observe after-tax income $y(1-\tau)$ and tangible assets $K$. They know that $x=y+N$ and must infer $x$ from the accounting report $(y(1-\tau), K)$. To do this, we assume that investors make a conjecture on date one that the firm invested $\theta K$ in intangible assets on date zero. ${ }^{6}$ Because $y$ and $K$ are reported on the firm's income statement and balance sheet, respectively, investors will infer that $x=y+\theta K$. The value of $\theta$ is derived endogenously from the firm's objective of maximizing the present value of the date one operating cash flow plus the date one expected price less the after-tax cost of its investments. Of course, the conjectured value of $\theta$ must be consistent with the firm's equilibrium investment decisions.

The price on date one is

$$
P=\frac{(1-\tau)(1-\lambda) E(x \mid y)+\lambda K(1+\rho)}{\rho+\lambda} .
$$

Using the relation $E(x \mid y)=y+\theta K$, (8) simplifies to

$$
P=\frac{(1-\tau)(1-\lambda)(y+\theta K)+\lambda K(1+\rho)}{\rho+\lambda} .
$$

On date zero, the firm maximizes the present value of the date one operating cash flow plus the date one expected price less the after-tax cost of the investments. Using the relation $E[y]=\mu f(K, N)-N$ yields the

\footnotetext{
${ }^{6}$ Other conjectures are possible, so this equilibrium is not unique. If, for example, investors conjectured that the firm would choose $N=\eta$, the firm's investment choices would be different but the result would be qualitatively similar; the firm would underinvest in intangible assets compared to the full information environment under the expensing regime.
} 
following maximization problem.

$$
\max _{K, N}\left\{\frac{(1-\tau) \mu f(K, N)+\lambda K}{\rho+\lambda}+\frac{(1-\tau)(1-\lambda)(\theta K-N)}{(1+\rho)(\rho+\lambda)}-K-N(1-\tau)\right\}
$$

The maximization problem in (10) is identical to the maximization problem in (5), except for the term $(1-\tau)(1-\lambda)(\theta K-N) /(1+\rho)(\rho+\lambda)$. This term captures the firm's incentive to underinvest in $N$ and overinvest in $K$ because the date one stock price reflects the inferred value of $N, \theta K$, rather than the value of $N$ itself. This creates a financial reporting disincentive to invest to intangibles, which counteracts the tax advantages from expensing. Proposition 2 summarizes these countervailing effects on the investment ratio.

Proposition 2. The investment ratio $N^{*} / K^{*}$ under the tax expensing regime in the accounting information environment is higher than under the tax capitalization regime in the full information environment if and only if

$$
\left[\frac{\tau}{1-\tau}\right]\left[\frac{\alpha}{\alpha+\beta}\right]>\frac{1-\lambda}{\rho(1+\rho)} .
$$

Proposition 2 shows that the claim that the expensing of internally developed intangible assets for tax purposes leads to excess investment in intangible assets need not hold in the accounting information environment. If the appropriate comparison is with the investment ratio $N^{*} / K^{*}$ in the benchmark capitalization case, then the aggregated disclosure case leads to either overinvestment or underinvestment in intangible assets. It is ambiguous as to whether the effect of the tax expensing regime is more or less important than the effect of the accounting information environment on $N^{*} / K^{*}$.

An examination of proposition 2 shows that whether the firm invests too much or too little in intangible assets relative to tangible assets in the aggregated disclosure case compared with the benchmark capitalization case depends on the terms $\tau /(1-\tau), \alpha /(\alpha+\beta)$, and $(1-\lambda) / \rho(1+\rho)$. The first term reflects the importance of taxes. The higher the tax rate, the more likely it is that the firm will overinvest in intangible assets in the aggregated disclosure case. The tax term is multiplied by the term $\alpha /(\alpha+\beta)$, which reflects the relative importance of tangible assets on output. Therefore, the greater the relative importance of tangible assets, the less likely it is that the firm will overinvest in tangible assets in the aggregated disclosure case. The last term reflects the importance of the date one stock price relative to the date one operating cash flow. If it is high (that is, if the first period operating cash flow is of little importance relative to date one stock price), then the firm will tend to underinvest in intangible assets in the aggregated disclosure case, despite the tax advantage of immediate expensing. Finally, when

$$
\left[\frac{\tau}{1-\tau}\right]\left[\frac{\alpha}{\alpha+\beta}\right]=\frac{1-\lambda}{\rho(1+\rho)}
$$

the tax and financial accounting effects are exactly offsetting, and the investment ratio in the aggregated disclosure case is equal to the investment ratio in the benchmark capitalization case. In other words, the tax incentives to invest in intangible assets are completely mitigated by financial reporting disincentives to invest in intangible assets.

The key is aggregation in the financial reports. Because the income statement subtracts investments in internally developed intangible assets $(N)$ from operating cash flows $(x)$ to arrive at net income $(y)$, the firm responds to short-term incentives to boost stock price by underinvesting in intangible assets. Note that investors are not being fooled here; the investment ratio that investors anticipate occurs in equilibrium. ${ }^{7} \mathrm{~A}$ firm that chose, for example, the investment ratio from the full information environment in Proposition 1(b) would drive down the date one price of the stock, as the unexpectedly high investment in intangibles would induce investors to underestimate the future operating cash flows $x$.

\footnotetext{
${ }^{7}$ The idea that managers act inefficiently, even with efficient capital markets, was first formally developed in a signal-jamming model in Stein (1989). The notion that managers make inefficient investment choices and that investors are not being fooled is also present in Kanodia et al. (2004).
} 
The aggregated disclosure case also provides the firm with an incentive to overinvest in tangible assets. As $\alpha$ approaches zero, $K^{*}$ approaches zero in the full information environment but not in the accounting information environment. This occurs because investing in $K$ increases the opportunity cost of underinvesting in $N$. Because investors can observe $K$ on the firm's balance sheet, the firm is willing to overinvest in $K$ to signal to investors that it has an incentive to invest in $N$ in the accounting information environment.

The effect of the accounting information environment on the investment ratio is exacerbated when $\lambda$ is low or when $\rho$ low. In either case, the date one operating cash flow becomes relatively less important than the date one stock price when determining the date zero stock price, which increases the firm's incentive to underinvest in intangible assets on date zero. The effect is also exacerbated by a lower value of $\alpha$ or a higher value of $\beta$. The more important intangible assets are to the production process, the greater is the distorting effect of accounting aggregation on the investment ratio.

\section{Tax preference measure}

In this section, we propose a tax preference measure that reflects the tax advantages of both investments in intangible assets and debt financing. In each case, the tax advantage does not change the firm's accounting effective tax rate, defined as the ratio of book-tax expense to pre-tax financial accounting income. This rate is often used as an indicator of tax-favored investments. In this setting, however, the accounting effective tax rate is of no use whatsoever. Immediate expensing of investments in internally developed intangible assets and interest payments for both financial accounting and tax purposes ensure that in every period, the accounting effective tax rate is $\tau$ in our model. This measure is unaffected by both the firm's use of funds (i.e., mix of tangible and intangible assets) and its source of funds (i.e., mix of debt and equity). The fact that the accounting effective tax rate reveals book-tax differences instead of tax preferences motivates our search for a different measure, which we call the economic effective tax rate.

We abstract away from the firm's choices of $K$ and $N$ in this section, which allows us to model the process by which assets decay in a less restrictive fashion. We also explicitly model the firm's capital structure in this section. On date zero, the firm invests $K$ dollars in tangible assets and $N$ dollars in intangible assets. Intangible assets decay at a constant rate $\lambda$; tangible assets decay at a constant rate $\delta$. Both types of assets are replaced as they decay. Investments in intangible assets are expensed for tax purposes when made; investments in tangible assets are capitalized when made and depreciated at their rate of economic decay $\delta$. Therefore, the after-tax cost of the initial investment is $K+N(1-\tau)$ and the book value of the firm's assets is $K$. The firm generates expected after-tax cash flows from its investments of $(1-\tau)[\mu f(K, N)-\delta K-\lambda N]$ per unit of time. This cash is distributed to debt holders in the form of interest and equity holders in the form of dividends.

We express the value of the firm using the adjusted-present-value (APV) method in which firm value is decomposed into the value of an all-equity firm and the tax savings from debt financing. The firm operates in an environment in which the value of the firm's debt $(D)$ and equity $(E)$ is equal to the after-tax cost of its investments. ${ }^{8}$ Debt holders are paid the risk-free rate of interest, $r$, which is deductible when determining the corporate income tax. The interest payments between equity holders and debt holders do not affect firm value, but the tax savings generated from the interest deductions provide the equity holders with a risk-free stream of cash flows of $\tau r D$. The after-tax cost of risky equity capital if the firm were an all-equity firm is $\pi$. Therefore

$$
\int_{0}^{\infty}(1-\tau)[\mu f(K, N)-\delta K-\lambda N] \mathrm{e}^{-\pi t} \mathrm{~d} t+\int_{0}^{\infty} \tau r D \mathrm{e}^{-r t} \mathrm{~d} t=K+N(1-\tau)=E+D .
$$

An equivalent representation of the value of the firm's debt and equity would be to discount the after-tax operating cash flows at the after-tax WACC $\rho$, which would yield

$$
\int_{0}^{\infty}(1-\tau)[\mu f(K, N)-\delta K-\lambda N] \mathrm{e}^{-\rho t} \mathrm{~d} t=K+N(1-\tau)=E+D .
$$

\footnotetext{
${ }^{8}$ This implies that the firm does not earn abnormal expected returns on its investments. A setting in which the firm earns abnormal expected returns on certain identified assets can be recharacterized as one in which the firm owns additional unidentified assets. Our definition of intangible assets is an expansive one.
} 
We focus on the first representation to highlight the role of tax-favored debt financing on both firm value and our tax preference measure. ${ }^{9}$

The pre-tax rate of return $R$ is the discount rate for which the present value of future pre-tax cash flows from the investments to all stakeholders (i.e., debt holders, equity holders, and the government) equals the pre-tax cost of the investments

$$
\int_{0}^{\infty}[\mu f(K, N)-\delta K-\lambda N] \mathrm{e}^{-R t} \mathrm{~d} t=K+N
$$

The right-hand side of (13) is in part financed by the government in two ways. First, the government provides a tax deduction for the initial investment in intangible assets of $\tau N$. Second, the government provides a subsidy with a present value of $\tau D$ in the form of future tax savings associated with interest expense. The remainder of the investment is financed by the bondholders and stockholders. Therefore, we express the investment provided by all stakeholders as $E+D+\tau N$ and the investment provided by bondholders and stockholders as $E+D(1-\tau)$. Using (13) and the fact that $K+N=E+D+\tau N$, we express the pre-tax rate of return $R$ on the investment provided by all stakeholders as

$$
R=\frac{\mu f(K, N)-\delta K-\lambda N}{E+D+\tau N} .
$$

The after-tax rate of return $\pi$ is the discount rate for which the present value of future after-tax cash flows from the project to private investors, $(1-\tau)[\mu f(K, N)-\delta K-\lambda N]$, equals the after-tax cost of the investments borne by private investors, $E+D(1-\tau)$. We use (11) to express the after-tax rate of return on investment provided by bondholders and stockholders as

$$
\pi=\frac{(1-\tau)[\mu f(K, N)-\delta K-\lambda N]}{E+D(1-\tau)} .
$$

The economic effective tax rate $\phi$ for the firm represents the total pre-tax rate of return from (14) minus the private after-tax rate of return from (15), expressed as a percentage of the total pre-tax rate of return:

$$
\phi=\frac{R-\pi}{R}=\tau-\frac{\tau N(1-\tau)}{E+D(1-\tau)}-\frac{\tau D(1-\tau)}{E+D(1-\tau)} .
$$

The upper bound for $\phi$ in (16) is $\tau$. If a firm has no tax-favored intangible investments (i.e., $N=0$ ) and no debt financing (i.e., $D=0$ ), the economic effective tax rate and the statutory tax rate are the same. The decomposition in (16) separates the effects of intangible investments and debt financing on the firm's economic effective tax rate. Our empirical estimate of $\phi$ in Section 5 shows that our tax preference measure varies by industry and over time in ways that provide important insights into the effect of these invisible tax preferences on sources and uses of firms' financing decisions.

We illustrate our model with the following example. A firm subject to a 35 percent tax rate invests $\$ 121$ million in a project on date zero. The investment in tangible capital $K$ is $\$ 81$ million and the remainder is in intangible capital $N$ so the after-tax cost of the initial investment is

$$
\$ 81,000,000+\$ 40,000,000(1-.35)=\$ 107,000,000 \text {. }
$$

The initial after-tax cost of the investment is provided by equity holders who provide $\$ 87,000,000$ and the remaining $\$ 20,000,000$ by debt holders who receive the risk-free rate of 6 percent. The cost of equity capital for an all-equity investment is 15.73 percent. The project generates an expected pre-tax cash flow in perpetuity of $\$ 24,200,000$; this amount includes amounts needed to replace tangible and intangible capital as they decay. The internal rate of return to all stakeholders is

$$
R=\frac{\$ 24,200,000}{\$ 121,000,000}=20 \% \text {. }
$$

\footnotetext{
${ }^{9}$ The APV method was introduced in Myers (1974). This valuation method calculates the net present value of the all-equity-financed project and adds the value of the tax benefits of debt. The weighted average cost of capital method accounts for any tax benefits of debt by adjusting the discount rate. The value of the tax benefits of debt in our model incorporate the assumption in Hamada (1972), which assumes that the tax shield is riskless and should be discounted back to date zero at the risk-free rate.
} 
Debt holders and equity holders together invest $\$ 107,000,000$, receiving a risky after-tax expected cash flow of $\$ 24,200,000(1-.35)=\$ 15,730,000$ and a risk-less cash flow of $\$ 20,000,000(.06)(.35)=\$ 420,000$ from the tax deduction for interest expense. The present value of the riskless future tax savings is $\$ 420,000 / .06=$ $\$ 7,000,000$. Using (15),

$$
\pi=\frac{\$ 15,730,000}{\$ 100,000,000}=15.73 \% .
$$

The economic effective tax rate is

$$
\phi=\frac{R-\pi}{R}=\frac{20-15.73 \%}{20 \%}=21.35 \% .
$$

Finally, we show that the firm's after-tax WACC satisfies (12). Using (12), the WACC must be

$$
\rho=\frac{\$ 15,730,000}{\$ 107,000,000} \approx 14.7 \% \text {. }
$$

By combining the Hamada (1972) model, in which both the debt and its tax shield are risk-free with the WACC equation, $\rho$ can be expressed as a function of $\pi$, and the firm's debt to value ratio ${ }^{10}$

$$
\rho=\pi\left[1-\frac{\tau D}{E+D}\right]
$$

\section{Empirical estimation}

In this section, we estimate our tax preference measure from (16) for the time period 1988 through $2005 . K$ is the book value of the firm's assets. $D$ is the book value of the firm's short-term and long-term interest-bearing debt. $E$ is the market value of the firm's equity plus the book value of its non-interest-bearing liabilities. ${ }^{11} \tau$ is the top statutory corporate tax rate of 34 percent for 1988-1992 and 35 percent for 1993-2005. Using the relation $K+N(1-\tau)=E+D$, we substitute $E+D-K$ for $N(1-\tau)$ in (16) for our empirical estimation. Accordingly, we proxy for intangible capital in our model as the difference between book value and market value of assets, consistent with our expansive definition of intangible assets. ${ }^{12}$

Because we use the difference between the book value and market value of firm assets as a proxy for intangible capital $N(1-\tau)$ in our model, firm-level estimates of economic effective tax rates are potentially misleading. Suppose five firms invest in an effort to be the first to discover a new drug. At the industry level, our measure recognizes the value of the discovery to the winning firm and the cost of the investments incurred by all five firms. At the firm level, however, the economic effective tax rate of the winning firm will be biased downward and the economic effective tax rates of the losing firms will be biased upward. To mitigate these effects, we use aggregate rather than firm-level measures of $K, D$ and $E$ to estimate economic effective tax rates in (16).

Our sample consists of 15,726 firms from the Compustat Industrial Annual File. We exclude 1363 foreign firms, partnerships, and subsidiaries and 5199 firms in untabulated industries. Table 2 reports the determination and industry makeup of the sample. We use the same industry classifications as in Barth et al. (1999).

\footnotetext{
${ }^{10}$ Grinblatt and Titman (2002, p. 482) formally prove this by showing that static perpetual debt in a WACC formula reduces to Modigliani and Miller's (1963) adjusted cost of capital formula, which gives the firm's WACC as a function of its debt to value ratio.

${ }^{11}$ In Compustat, $K$ is defined as data6; $D$ is defined as data9+ data34; $E$ is defined as data25 $\times$ data199+data6-data60-data9-data34. For financial firms, interest bearing debt (included in our measure of $D$ ) also includes data53 from the annual bank file (i.e., bna).

${ }^{12} \mathrm{We}$ emphasize that our paper deals with investments in internally developed intangible assets. When intangible assets are purchased externally, the value of these intangibles is reflected (i.e., the assets are "stepped-up") in the book value of a firm's assets if purchase accounting was used for GAAP. Where purchase accounting was used but there was no corresponding step-up in basis for tax purposes, our economic effect tax rate measure will be overstated. This is because our measure will detect fewer tax-favored investments in internally developed intangible assets, causing the effect of intangible assets of our tax preference measure to be understated. If the accounting and tax treatments of externally purchased intangibles are the same (i.e., a step-up in basis of assets for both or neither), then our economic effective tax rate will properly reflect this tax preference.
} 
Table 2

Sample determination and industry distribution

\begin{tabular}{lll}
\hline Sample determination & & $N$ \\
\hline All firms on Compustat (Industrial Annual) & & 22,288 \\
Partnerships, subsidiaries, foreign firms & & 1363 \\
Firms in untabulated industries & & 5199 \\
Final sample & & 15,726 \\
Industry distribution & Standard industrial classification & $\mathrm{N}$ \\
\hline Mining & $1000-1999$, excluding $1300-1399$ & 445 \\
Food & $2000-2111$ & 273 \\
Textiles & $2200-2790$ & 598 \\
Chemicals & $2800-2824,2840-2899$ & 269 \\
Pharmaceuticals & $2830-2836$ & 696 \\
Extractive & $2900-2999,1300-1399$ & 586 \\
Durables & $3000-3999$, excluding $3570-3579$ and $3670-3680$ & 2869 \\
Computers & $7370-7379,3570-3579,3670-3679$ & 2380 \\
Transportation & $4000-4899$ & 839 \\
Utilities & $4900-4999$ & 358 \\
Retail & $5000-5999$ & 1510 \\
Insurance & $6500-6999$ & 748 \\
Services & $7000-8999$, excluding $7370-7379$ & 1611 \\
Financial & $6000-6411$ & 2544 \\
\hline
\end{tabular}

Table 3 (Panels A and B) report our empirical estimate of the economic effective tax rate $\phi$ by year and by industry, respectively. We show both $\phi$ and the decomposition of our measure as in (16). The column denoted "Effect of Intangible Assets" shows the effect of investments in intangible assets on the economic effective tax rate. The column denoted "Effect of Debt Financing" shows the effect of tax-deductible interest payments on the economic effective tax rate.

In Panel A, we use aggregate measures of $K, E$, and $D$ for all firms in our sample for each year to compute the effect of intangible assets and debt financing of the economic effective tax rate. This method produces a value-weighted estimate of $\phi$ for each year, which represents an economy-wide tax rate measure for each year during our sample period. Our results show the average value of $\phi$ is 18 percent, during which time the top statutory rate was either 34 percent (1988-1992) or 35 percent (1993-2005). On average, the statutory tax rate is reduced by 9 percentage points due to immediate expensing of intangible assets. The use of debt financing further reduces the statutory tax rate by 8 percentage points.

Table 3 (Panel A) also shows a general decline in the economic effective tax rate over time. The average measure declines from 22 percent in 1988 to 17 percent in 2005. This downward trend is consistent with the growing importance of intangible assets in the economy from 1988 through 2005. Additionally, investments in intangible assets play a more significant role over time relative to debt financing in reducing the economic effective tax rate below the statutory rate.

McGrattan and Prescott (2000) estimate the average magnitude of intangible capital stock for the corporate sector using data from 1990 through 1999 and, consistent with our paper, they take an expansive view of intangible capital. Therefore, a comparison of our estimate with theirs is appropriate. ${ }^{13}$ In their Table 1 they estimate measured (i.e., tangible) capital to be 104.2 percent of GNP and unmeasured (i.e., intangible) capital to be 64.5 percent on GNP, yielding a ratio of intangible capital to tangible capital of .62. This ratio corresponds to our ratio of $N / K$. For our entire sample, the ratio of the book value of assets to the market value of equity plus the book value of interest-bearing debt is $K /(E+D)=76 \%$. Using the relation $E+D=K+N(1-\tau)$, this implies that the average ratio of investment in intangible assets to tangible assets

\footnotetext{
${ }^{13}$ We thank the referee for suggesting the link between the McGrattan and Prescott paper and our paper in terms of measuring intangible capital stock in the corporate sector.
} 
Table 3

Economic effective tax rates

\begin{tabular}{|c|c|c|c|}
\hline \multicolumn{4}{|c|}{$\begin{array}{l}\text { Panel A: By year }{ }^{\mathrm{a}} \\
\qquad \phi=\tau-\frac{\tau N(1-\tau)}{E+D(1-\tau)}-\frac{\tau D(1-\tau)}{E+D(1-\tau)}\end{array}$} \\
\hline Year & Effect of intangible assets $\frac{\tau N(1-\tau)}{E+D(1-\tau)}$ & Effect of debt financing $\frac{\tau D(1-\tau)}{E+D(1-\tau)}$ & Economic effective tax rate $\phi$ \\
\hline 1988 & .05 & .08 & .22 \\
\hline 1989 & .06 & .07 & .20 \\
\hline 1990 & .05 & .08 & .22 \\
\hline 1991 & .07 & .07 & .20 \\
\hline 1992 & .08 & .07 & .19 \\
\hline 1993 & .08 & .07 & .20 \\
\hline 1994 & .07 & .08 & .20 \\
\hline 1995 & .09 & .07 & .18 \\
\hline 1996 & .10 & .07 & .18 \\
\hline 1997 & .12 & .07 & .16 \\
\hline 1998 & .12 & .07 & .15 \\
\hline 1999 & .14 & .07 & .14 \\
\hline 2000 & .13 & .07 & .15 \\
\hline 2001 & .11 & .08 & .16 \\
\hline 2002 & .08 & .10 & .17 \\
\hline 2003 & .09 & .09 & .17 \\
\hline 2004 & .10 & .09 & .17 \\
\hline 2005 & .09 & .09 & .17 \\
\hline Mean & .09 & .08 & .18 \\
\hline \multicolumn{4}{|c|}{$\begin{array}{l}\text { Panel B: By industry }{ }^{\mathrm{b}} \\
\qquad \phi=\tau-\frac{\tau N(1-\tau)}{E+D(1-\tau)}-\frac{\tau D(1-\tau)}{E+D(1-\tau)}\end{array}$} \\
\hline Industry & Effect of intangible assets $\frac{\tau N(1-\tau)}{E+D(1-\tau)}$ & Effect of debt financing $\frac{\tau D(1-\tau)}{E+D(1-\tau)}$ & Economic effective tax rate $\phi$ \\
\hline Mining & .12 & .05 & .18 \\
\hline Food & .19 & .04 & .12 \\
\hline Textile & .12 & .05 & .17 \\
\hline Chemical & .16 & .04 & .15 \\
\hline Pharmaceutical & .25 & .01 & .09 \\
\hline Extractive & .13 & .04 & .18 \\
\hline Durables & .10 & .07 & .18 \\
\hline Computers & .18 & .02 & .14 \\
\hline Transportation & .12 & .05 & .17 \\
\hline Utilities & .06 & .09 & .20 \\
\hline Retail & .15 & .04 & .16 \\
\hline Insurance & .07 & .12 & .16 \\
\hline Services & .13 & .05 & .16 \\
\hline Financial & .03 & .11 & .21 \\
\hline Variance & 0.0030 & 0.0009 & 0.0008 \\
\hline Correlation & -0.90299 & & \\
\hline
\end{tabular}

\footnotetext{
${ }^{\text {a }}$ We estimate $N(1-\tau)$ using the relation $E+D=K+N(1-\tau)$. $E$ is the market value of the firm's equity plus the book value of its noninterest bearing liabilities. $D$ is the book value of the firm's short-term and long-term interest-bearing debt. $K$ is the book value of the firm's assets. $\tau$ is the top corporate tax rate. We compute $\phi$ using aggregate measures of $E, D$, and $K$ by industry for each year.

${ }^{\mathrm{b}}$ We estimate $N(1-\tau)$ using the relation $E+D=K+N(1-\tau)$. $E$ is the market value of a firm's equity plus the book value of its noninterest bearing liabilities. $D$ is the book value of a firm's short-term and long-term interest-bearing debt. $K$ is the book value of a firm's assets. $\tau$ is the top corporate tax rate. We compute $\phi$ using aggregate measures of $E, D$, and $K$ for the entire sample by year.
} 
for our sample from 1990 through $1999, N / K$, is about .50. Our ratio is roughly comparable to theirs, and even appears to be a relatively conservative estimate of intangible assets in the corporate sector. Therefore, to the extent there is bias in our economy-wide estimate of investments in intangible assets, such bias is likely to understate the effect of these investments on our economic effective tax rate.

Table 3 (Panel B) shows our economic effective tax rate measure by industry. We compute aggregate measures of $K, E$, and $D$ by year for each industry. We then compute a simple average for each industry over the time period. The effect of investments in intangible assets on the economic effective tax rate varies across industries from 3 percent to 25 percent. This effect is highest for industries with a relatively intensive use of intangible capital - pharmaceuticals ( 25 percent), chemicals (16 percent), food (19 percent), and computers (18 percent). The effect is lowest for industries with a relatively intensive use of tangible and financial assetsutilities ( 6 percent), insurance ( 7 percent), and financial services ( 3 percent).

While the expensing of interest payments for both tax and financial reporting purposes does not lower a firm's accounting effective tax rate, debt financing is tax-favored relative to equity financing because payments to debt holders are tax deductible. While the effect of debt financing on the economic effective tax rate remained relatively stable over our time period, the effect does vary by industry.

Industries with a relatively intensive use of intangible capital have the lowest effect of debt financing on the economic effective tax rate. Table 3 (Panel B) shows that the smallest effect of debt financing on the economic effective tax rate occurs in the pharmaceutical and computer industries, with a 1 and 2 percentage point decrease, respectively. The largest effect of debt financing on the economic effective tax rate occurs in industries with a relatively intensive use of tangible and financial assets, such as utilities and financial services, with a 9 and 11 percentage point decrease, respectively.

The correlation coefficient of the two effects on our measure, intangible assets and debt financing, is - 903 . We conjecture that this relation exists because firms with high levels of intangible assets relative to tangible assets have limited collateral against which to borrow, making debt financing potentially more costly for those firms than for firms with a significant tangible asset base. ${ }^{14}$ The use of debt financing appears to play a more significant role in reducing the economic effective tax rate for firms with a relatively intensive use of tangible or financial assets. As a result, the intra-industry variance of our measure is reduced when financing and investment are considered together, rather than just looking at the effect of intangible assets in isolation (i.e., .0008 versus .0030).

\section{Conclusions}

Our study of the tax and financial reporting issues associated with investment in internally developed intangible assets yields two important insights. Because investors cannot distinguish between intangible investments and operating expenses in our model, managers have an incentive to underinvest in intangibles despite their favorable tax treatment. The net effect of financial reporting costs and tax benefits could increase or decrease the ratio of investment in intangible assets to tangible assets relative to a hypothetical benchmark case in which such intangible investments were capitalized for tax purposes and investors could distinguish intangible investments from operating expenses. These findings suggest that the financial reporting treatment of investments in intangible assets mitigates the tax incentives that encourage such investments.

Second, we develop a tax preference measure that detects investments in intangible assets and the use of debt financing, which are both tax-favored but do not generate book-tax differences. Our measure indicates that the economic effective tax rate was, on average, about 18 percent between 1988 and 2005. This rate varies substantially by industry, from a low of 9 percent for the pharmaceutical industry and a high of 21 percent for financial services firms. Additionally, we find that the effect of debt financing on the economic effective tax rate is smaller for firms with relatively high levels of intangible assets relative to tangible assets. These findings suggest accounting-based tax preference measures fail to reflect important tax preferences. In addition, because the effects of the two tax preferences on our measure are negatively related, this suggests that any

\footnotetext{
${ }^{14}$ Another possible interpretation of this relation is that firms with a relatively intensive use of intangible assets for which investments are immediately expensed may find themselves in a tax loss position, which would increase the after-tax cost of interest.
} 
analysis of intra-industry variation in tax-favored investment should consider both the uses and sources of corporate financing.

\section{Appendix A}

\section{Proof of proposition 1.}

(a) Differentiating (4) with respect to $K$ and $N$ yields the following first-order conditions.

$$
\begin{aligned}
& \frac{(1-\tau) \mu q_{K}}{\rho}=1 \\
& \frac{(1-\tau) \mu q_{N}}{\rho+\lambda(1-\tau)}=1
\end{aligned}
$$

Setting the left-hand side terms from (A.1) and (A.2) equal to each other and substituting in the partial derivatives of (2) with respect to $K$ and $N$ yields the result.

(b) Differentiating (5) with respect to $K$ and $N$ yields the following first-order conditions where $\partial f(K, N) / \partial K=q_{K}$ and $\partial f(K, N) / \partial N=q_{N}$.

$$
\begin{aligned}
& \frac{(1-\tau) \mu q_{K}}{\rho}=1 \\
& \frac{\mu q_{N}}{\rho+\lambda}=1
\end{aligned}
$$

Setting the left-hand side terms from (A.3) and (A.4) equal to each other and substituting in the partial derivatives of (2) with respect to $K$ and $N$ yields the result.

Proof of Proposition 2. We first derive the equilibrium investment ratio $N^{*} / K^{*}=\theta$ in case 3. Differentiating (10) with respect to $K$ and $N$ yields the following first-order conditions:

$$
\begin{aligned}
& \frac{(1-\tau) \mu q_{K}(1+\rho)}{\rho(1+\rho)-\theta(1-\lambda)(1-\tau)}=1, \\
& \frac{\mu q_{N}(1+\rho)}{1+\rho+\rho^{2}+\rho \lambda}=1 .
\end{aligned}
$$

(A.5) and (A.6) jointly imply

$$
\frac{N^{*}}{K^{*}}=\frac{\beta[\rho(1+\rho)-\theta(1-\lambda)(1-\tau)]}{\alpha(1-\tau)\left(1+\rho+\rho^{2}+\rho \lambda\right)} .
$$

The investors' conjecture that $N=\theta K$ must be confirmed in equilibrium, which implies

$$
\theta=\frac{\beta \rho(1+\rho)}{(1-\tau)\left[\alpha\left(1+\rho+\rho^{2}+\rho \lambda\right)+\beta(1-\lambda)\right]} .
$$

Substituting the value of $\theta$ from (A.8) into (A.7) yields the result. Dividing the investment ratio from (8) by the investment ratio from Proposition 1(a) and simplifying yields the result.

\section{References}

Barth, M., Beaver, W., Hand, J., Landsman, W., 1999. Accruals, cash flows, and equity values. Review of Accounting Studies 3, $205-229$. Blair, M., Wallman, M.H., 2001. Unseen Wealth: Report of the Brookings Task Force on Intangibles. Brookings Institution Press, Washington, DC.

Dunbar, A., Sansing, R., 2002. Measuring corporate tax preferences. Journal of the American Taxation Association 24 (Fall), 1-17. 
Fullerton, D., Lyon, A., 1988. Tax neutrality and intangible capital. In: Summers, L. (Ed.), Tax Policy and the Economy, vol. 2. MIT Press, Cambridge, MA.

Gravelle, J., 1994. The Economic Effects of Taxing Capital Income. The MIT Press, Cambridge.

Grinblatt, M., Titman, S., 2002. Financial Markets and Corporate Strategy, second ed. McGraw-Hill Irwin, New York City, NY.

Gupta, S., Newberry, K., 1992. Corporate average effective tax rates after the Tax Reform Act of 1986. Tax Notes 55, 689-698.

Hamada, R., 1972. The effect of a firm's capital structure on the systematic risk of common stocks. Journal of Finance 27, 435-452.

Kanodia, C., Mukherji, A., 1996. Real effects of separating operating and investment cash flows. Review of Accounting Studies 1 (March), $51-72$.

Kanodia, C., Sapra, H., Venugopalan, R., 2004. Should intangibles be measured: what are the economic trade-offs? Journal of Accounting Research 42 (March), 89-120.

Lev, B., 2001. Intangibles: Management, Measurement, and Reporting. Brookings Institution Press, Washington, DC.

McGrattan, E., Prescott, E., 2000. Is the stock market overvalued? Federal Reserve Bank of Minneapolis Quarterly 24 (4 (Fall)), $20-40$.

Modigliani, F., Miller, M., 1963. Corporate income taxes and the cost of capital: a correction. American Economic Review 48 (3), 261-297.

Myers, S., 1974. Interactions of corporate financing and investment decisions-implications for capital budgeting. Journal of Finance 29 (1), $1-25$.

Myers, S., 1977. Determinants of corporate borrowing. Journal of Financial Economics 5, 146-175.

Neubig, T., 2006. Where's the applause? Why most corporations prefer a lower rate. Tax Notes 111 (April 24), 689-698.

Shackelford, D., Slemrod, J., Sallee, J., 2006. A unifying model of how taxes affect the real and accounting decisions of corporations. University of North Carolina and University of Michigan Working Paper.

Shevlin, T., Porter, S., 1992. The corporate tax comeback in 1987: some further evidence. Journal of the American Taxation Association $14,58-79$.

Smith Jr., C.W., Watts, R.L., 1992. The investment opportunity set and corporate financing, dividend, and compensation policies. Journal of Financial Economics 32, 263-292.

Stein, J., 1989. Efficient capital markets, inefficient firms: a model of myopic corporate behavior. Quarterly Journal of Economics 104 (November), 655-669.

Sullivan, M., 2006. Germany's reluctant reformer bows to the inevitable. Tax Notes International 43 (July 10), 102-104.

Wilkie, P., 1992. Empirical evidence of implicit taxes in the corporate sector. Journal of the American Taxation Association 14, $97-116$.

Wilkie, P., Limberg, S., 1993. Measuring explicit tax (dis)advantage for corporate taxpayers: an alternative to average effective tax rates. Journal of the American Taxation Association 15, 46-71. 